\title{
Mengatur Kecepatan Motor DC dengan menggunakan Metode Fuzzy pada Alat Perontok Padi
}

\author{
Controlling DC Motor Speed With Fuzzy Method \\ On Rice Thresher Machine
}

\author{
Anton Hidayat, Nasrullah \& Ramiati \\ Jurusan Teknik Elektro Politeknik Negeri Padang Kampus Unand Limau Manis Padang \\ E-mail Antonramiati@gmail.com
}

\begin{abstract}
In designing this device, the rice thresher will be lighter, so it will be easier in lifting, simpler in using so farmers as main users will easier in operating this instrument with featuring speed controllable by applying fuzzy method, and also no fossil fuels used because it utilize sunshine as green energy to drive DC motor. Solar cells are used to absorb sunshine in rice thresher machine because it easier in maintenance. The test results of the rice thresher machine is the reduction of the avarage motor speed by 195 rpm every each five rice straws, in the other hand the maximum electric current is needed to spin the rice threser is 6 ampere and minimum electric current is 2.2 ampere. Furthermore, to stabilize motor speed at $2000 \mathrm{rpm}$, the avarage time required is 6 seconds when this machine loaded with rice straws. The eficiency of the rice thresher machine is $96 \%$, it mean the avarage time to thresh the rice is 9 rice straws every each seconds.
\end{abstract}

Keywords : Rice Thresher, Solar Cell, Fuzzy, DC Motor.

\section{PENDAHULUAN}

Beras merupakan makan pokok masyarakat indonesia, dengan makin bertambahnya penduduk maka kebutuhan akan beras sangat tinggi sedangkan pertumbuhan lahan untuk bertanam padi sangat sedikit, sehingga pengoptimalan hasil panen padi di masyarakat sangat dibutuhkan agar hasil panen gabah lebih meningkat. Untuk meningkatkan hasil panen padi pemerintah sudah mengusahkan dengan memberikan bibit unggul dan teknik penanaman yang baik serta pupuk bersubsidi kepada petani di indonesia. Program pemerintah juga mengusahakan indonesia menjadi negara suasembada beras sehingga indonesia tidak mengimpor beras dari negara lain. Pada tahun 1986, Presiden RI mengeluarkan Keputusan Presiden No. 47/ 1986 tentang Peningkatan Penanganan Pascapanen Hasil Pertanian Hal ini menunjukkan besarnya perhatian pemerintah terhadap upaya penyelamatan hasil panen.

Proses perontok dan pembersih gabah kering padi adalah aktivitas kerja dari sebuah sistem mesin yang dilaksanakan secara manual. Disini kinerja proses akan sangat tergantung sepenuhnya pada manusia, baik dalam hal penggunaan tenaga maupun pengendalian kerja. Pada perancangan alat ini akan dibuat lebih ringan agar mudah diangkat, sederhana penggunaannya agar mudah dioperasikan oleh petani dan dapat diatur kecepatannya dengan menggunakan metode fuzzy sesuai kebutuhan dan juga tidak menggunakan bahan bakar fosil dalam penggunaanya sebab menggunakan cahaya matahari sebagai sumber energi untuk mengerakan motor DC. Solar Cell yang digunakan sebagai alat penerima sumber cahaya matahari dan juga dimanfaatkan sebagai tempat berteduh pada proses perontokan padi, serta murah dalam perawatannya.

\section{METODOLOGI}

\section{Penelitian Tentang Upaya Peningakatan Hasil Pertanian \\ Masalah utama dalam penanganan pascapanen padi adalah tingginya kehilangan hasil (BPS 1988, 1996), serta}


gabah dan beras yang dihasilkan bermutu rendah. Hal ini terjadi pada tahapan pemanenan, perontokan, dan pengeringan sehingga perbaikan teknologi pascapanen padi dititik beratkan pada ketiga tahapan tersebut dan dari data BPS menunjukan makin berkurangnya tenaga kerja dibidang pertanian disebabakan masyarakat yang cendrung ingin ke kota untuk mencari pekerjan dalam bidang industri, menyebabkan kesulitan petani dalam tahap pemanenan ini disebabkan waktu pemanenan yang singkat dan dibutuhkan tenaga petani yang banyak [Agus, 2010]. Penanganan panen dan pascapanen padi memiliki kontribusi cukup besar terhadap pengamanan produksi beras nasional. Kehilangan hasil akibat penanganan panen dan pascapanen yang tidak sempurna mencapai $20,51 \%$. Jika produksi padi nasional mencapai 54,34 juta ton maka kerugian tersebut setara dengan Rp15 triliun maka kesiapan teknologi panen dan pascapanen padi dalam upaya menekan kehilangan hasil dan meningkatkan mutu beras serta pemahaman petani/pengguna teknologi terhadap upaya menekan kehilangan hasil panen. Teknologi dimaksud mencakup penentuan umur panen, cara panen, perontokan gabah, pengeringan, penggilingan, pelembutan lapisan aleuron, dan peningkatan mutu beras [kasma, 2012].

Dalam pengujian hal yang harus dilakukan adalah:

\section{a. Peralatan}

Semua alat uji yang digunakan adalah alat yang telah dikalibrasi ketepatannya dan terdiri dari:
1) Timbangan dengan ketepatan ketelitian gg,0 \%
2) Tachometer dengan ketelitian $1 \%$.
3) Alat pengukur kadar air (moisture tester) jenis non destruktip.
4) Kaca pembesar
5) Stopwatt.
6) Mistar pengukur (roll meter)
7) Dynamometer
8) Multimeter

\section{b. Kondisi bahan baku}

1) Varitas padi yang digunakan harus sama

2) Padi telah terontok dan telah terhitung beratnya

3) Kadar air harus seragam kira-kira $21 \%-27 \%$

4) Kadar gabah rata-rata pada padi harus diketahui.

5) Kadar butir retak, butir patah dalam padi diketahui.

\section{c. Kondisi mesin}

1) Kecepatan putar mesin diatur pada kondisi optimum dan diketahui kecepatannya.

2) Mesin yang digunakan harus kokoh, kuat dan aman.

3) Pengujian dilakukan seteiah mesin berjalan stabil.

\section{d. Pelaksanaan Pengujian Kapasitas Alat}

Sediakan padi sesuai dengan besarnya kapasitas perkiraan alat yang akan diuji. Padi masukkan ke dalam mesin. Gabah ditampung dalam waktu 25- 45 menit (tergantung kapasitas mesin yang diuji). Catat waktu pembersihan dan timbang hasilnya. Ulangan dilakukan minimum 5 kali, kemudian dirata-ratakan.

Perhitungan :

$$
\mathrm{K}=\frac{\mathrm{Bg}}{\mathrm{t}} \times 60
$$

dimana :

$\mathrm{K}=$ kapasitas pembesih ( $\mathrm{kg} / \mathrm{jam})$

$\mathrm{Bg}=$ berat gabah yang dihasilkan $(\mathrm{kg})$

$\mathrm{t} \quad$ = waktu yang dibutuhkan (menit)

\section{e. Efisiensi Pembersih}

Timbang gabah yang sudah dibersihkan dan.yang tidak bersih dari hasil alat Seed Cleaner. Gabah yang sudah dibersihkan adalah seluruh jumlah gabah yang terlepas dari malai. perhitungan : 
dimana :

$$
\eta_{\mathrm{p}}=\frac{\mathrm{B}_{\mathrm{GR}}}{\mathrm{B}_{\mathrm{GR}}+\mathrm{B}_{\mathrm{GTR}}} \times 100 \%
$$

$\eta \mathrm{p}=$ efisiensi Pembersih (\%)

BGR = bobot gabah yang bersih $(\mathrm{kg})$

BGTR = bobot gabah kotor $(\mathrm{kg})$

\section{Sensor Kelembaban}

Sensor kelembaban tanah adalah sensor yang digunakan untuk melakukan pengukuran kelembapan tanah. Prinsip kerja sensor kelembaban tanah adalah memberikan nilai keluaran berupa besaran listrik saebagai akibat adanya air yang berada diantara lempeng kapasitor sensor tersebut. Praktikum ini menggunakan dua sensor untuk mengukur kelembaban tanah yaitu sensor SEN0114 dan VN400. Praktikum ini bertujuan untuk mengenal berbagai macam tipe sensor kelembaban tanah, mengetahui spesifikasi sensor kelembaban tanah, dan membuat program arduino untuk membaca output sensor kelebaban tanah. Praktikum ini menggunakan metode pengukuran tidak langsung dengan menggunakan sensor. Sensor SEN0114 dan VN400 digunakan untuk mengukur kelembaban tanah. Spesifikasi sensor SEN0114 yaitu dapat bekerja pada tegangan $3.3-5 \mathrm{~V}$, memiliki arus yang rendah yaitu sekitar $35 \mathrm{~mA}$, dan memiliki nilai keluaran $0-4,2 \mathrm{~V}$. Spesifikasi sensor VN400 yaitu outputnya mencapai $0-3 \mathrm{~V}$, rentang ukur antara -40 sampai $-85{ }^{\circ} \mathrm{C}$, dan akurasinya mencapai 2 $\%$. Sensor VN400 merupakan sensor yang membaca nilai kelembaban berdasarkan konstanta dielektrik tanah yang diukur dengan transmission-line technique saat dialiri listrik oleh lengan sensor. Nilai kelembaban yang dihasilkan oleh sensor VN400 lebih akurat dibandingkan sensor SEN0114. Kelembaban tanah contoh uji yang diperoleh sensor VN400 berkisar antara $29,34-56,78 \%$, sedangkan kelembaban tanah contoh uji oleh sensor SEN0114 berkisar antara $68-69 \%$.

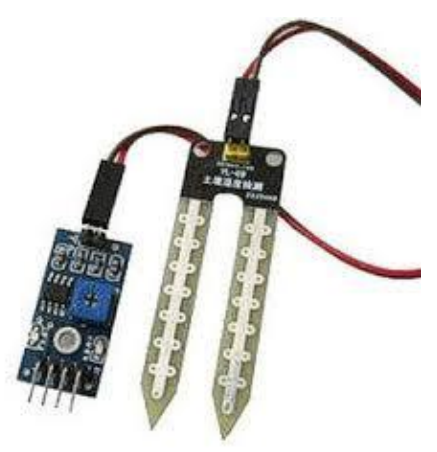

\section{Gambar 1. Sensor Kelembaban Soil Moisture}

Soil Moisture Sensor Module adalah suatu modul yang berfungsi untuk mendeteksi tingkat kelembaban tanah dan juga dapat digunakan untuk menentukan apakah ada kandungan air di tanah/ sekitar sensor. Cara penggunaan modul ini cukup mudah, yakni dengan memasukkan sensor ke dalam tanah dan setting potensiometer untuk mengatur sensitifitas dari sensor. Keluaran dari sensor akan bernilai 1 / 0 ketika kelembaban tanah menjadi tinggi/ rendah yang dapat di treshold dengan potensiometer.

\section{Motor DC}

Motor DC adalah merupakan bagian utama dari sebuah alat perontok padi otomatis dalam sistem penelitian ini. Motor DC yang digunakan dalam penelitian ini adalah motor DC penetary dengan kecepatan maksimum adalah 2000 RPM. Motor DC lebih cocok digunakan pada aplikasi yang menggunakan kecepatan tinggi dan torsi yang cukup besar. Oleh karena itu, motor ini biasanya digunakan pada bagian roda atau kaki sebagai penggerak dari sebuah robot. MTRDSR01 yang tampak pada gambar 1 adalah sebuah motor yang dilengkapi dengan rotary encoder sehingga sistem dapat mengetahui kecepatan putar dari motor tersebut.

Kecepatan putar motor dihitung berdasarkan jumlah putaran yang terjadi dalam satu menit atau RPM (Rotation Per Minute). 


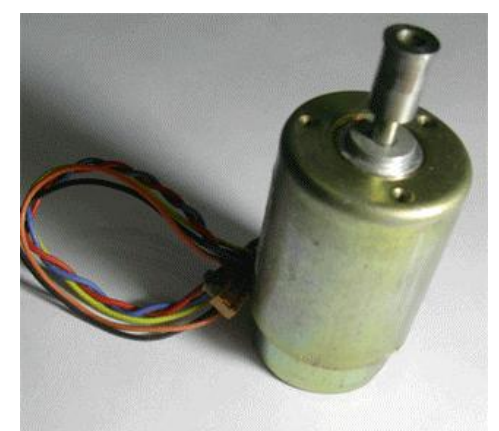

Gambar 2. Motor DC

\section{Kontrol Fuzzy}

Fuzzy Logic Controller merupakan alternatif sistem kendali modern yang mudah karena tidak perlu dicari model matematis dari suatu sistem, tetapi tetap efektif karena memiliki respon sistem yang stabil. Alat pembuat gerabah yang direncanakan diputar oleh motor DC yang dikontrol oleh mikrokontroler dan metode pengaturan yang digunakan adalah fuzzy logic. Fuzzy logic yang dirancang memiliki 2 input (Err \& DErr) dan 1 output (Doutput). Masing-masing membership function memiliki 5 label. Disini digunakan 25 fuzzy if-then rule yang terdiri atas 9 rule pokok/utama, 10 rule tambahan dan 6 rule pelengkap. Sedangkan proses fuzzy logic terdiri dari fuzzifikasi, evaluasi rule dan yang terakhir defuzzifikasi. Penggerak motor (driver motor) menggunakan sistem PWM (Pulse Width Modulation). Input Setting Point dibatasi antara 0 sampai dengan 255 RPM sesuai dengan yang dibutuhkan [Resmana, 1999].

Pemanfaatan PWM di dalam rangkaian sistem kontrol mikrokontroler yaitu untuk mengatur kecepatan putaran motor, sehingga motor akan berputar sesuai dengan besaran nilai PWM yang telah diberikan. Nilai PWM yang dibangkitkan dari mikrokontroler ini yaitu dengan cara melakukan perhitungan dari metode logika fuzzy. Pengujian PWM ini menggunakan oscilloscope untuk mengetahui bentuk gelombangnya. PWM ini dapat dibangkitkan dari pin khusus timer/counter1 port D4 dan D5 mikrokontroler. Sehingga dapat diatur mode dan cara kerja PWM sedemikian rupa.

\section{Perancangan Sistem}

\section{Perancangan Sistem}

Perancangan sistem meliputi hal-hal yang berhubungan dengan diagram blok, perancangan hardware, perancangan software dan perancangan papan rangkaian tercetak (PCB).

Dalam perancangan rangkaian harus diperhitungkan nilai ekonomis dari penggunaan komponen. Sebelum membuat rangkaian dan sistem, terlebih dahulu direncanakan blok diagram yang nantinya mempunyai satu tujuan agar rangkaian yang dibuat mengarah pada tujuan yang diinginkan.

Diagram blok menggambarkan secara umum bagaimana cara kerja rangkaian secara keseluruhan 


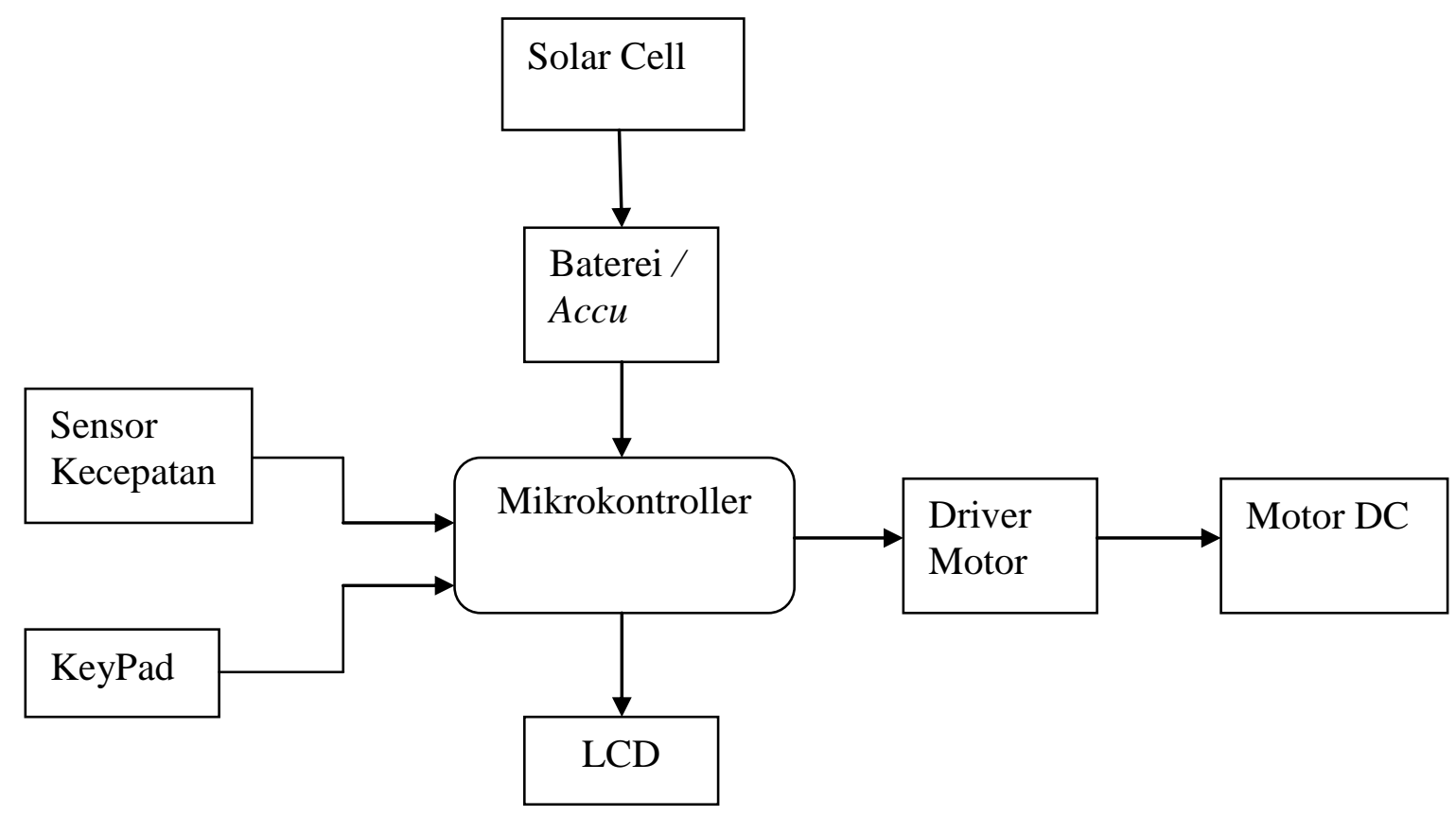

Gambar 3. Perancangan Sistem kendali Mesin Perontok Padi dan Pemisah Gabah Kering

Peralatan kontrol yang dibuat menggunakan sistem mikrokontroler Arduino yang merupakan sistem minimum untuk pengaturan kecepatan motor DC. Motor yang digunakan untuk alat ini adalah motor penatari, dimana kemampuan torsi dari motor ini sangat besar dan kecepatan motor dapat diatur dengan menggukan sistem PWM (Pulse Wide Modulation) sehingga didapatkan kecepatan yang cocok untuk mesin perontok padi. Metode yang digunakan untuk mengatur kecepatan motor DC ini mengunakan sistem cerdas Fuzzy Logic dimana aplikasi fuzzy logic terhadap pengaturan kecepatan motor DC ini sangat cocok dengan perubahan beban yang bervariasi. Perancangan alat yang telah dikerjakan pada penelitian dapat dilihat pada gambar 4.2. dimana alat tersebut belum sempurna karena masih terdapat beberapa kekurangan kemampuan motor untuk merontokan padi belum sempurna dan juga padi yang akan dirontokan juga tidak bisa banyak karena kemampuan motor yang kurang. Juga pada sistem sebelumnya tidak menggunakan sistem kontrol jadi belum ada pengaturan kecepatan motor, dan juga untuk baterai belum menggunakan solar cell sebagai alat charge accu sehingga kemampuan alat terbatas..
Pada Alat Pembersih Gabah Kering dibentuk sedemikian rupa agar didapatkan proses pembersihan yang optimum pada pembuatan pembersih gabang kering sebelumnnya dalam penelitian ini sensor yang digunakan adalah sensor kelembaban agar peneliti dapat mengetahui tingkat kelembaban dari gabah sehingga putaran motor dapat menyesuaikan apakah gabah dalam kondisi kering atau basah. Dalam pengujian ini masih didapatkan kekurangan terutama pada proses pengipasan dimana motor yang digunakan masih menggunakan motor DC sehingga pada proses pemutaran kipas tidak optimal dengan menggunakan motor penetary akan didapatkan kecepatan yang optimal. Dengan memberikan tambahan solar cell sebagai sumber energi sehingga penggunaanya dapat dilakukan lebih lama dengan memanfaatkan cahaya matahari sebagai sumber pada Gambar 2 . dapat dilihat gambar mesin Pembersih Gabah kering. 


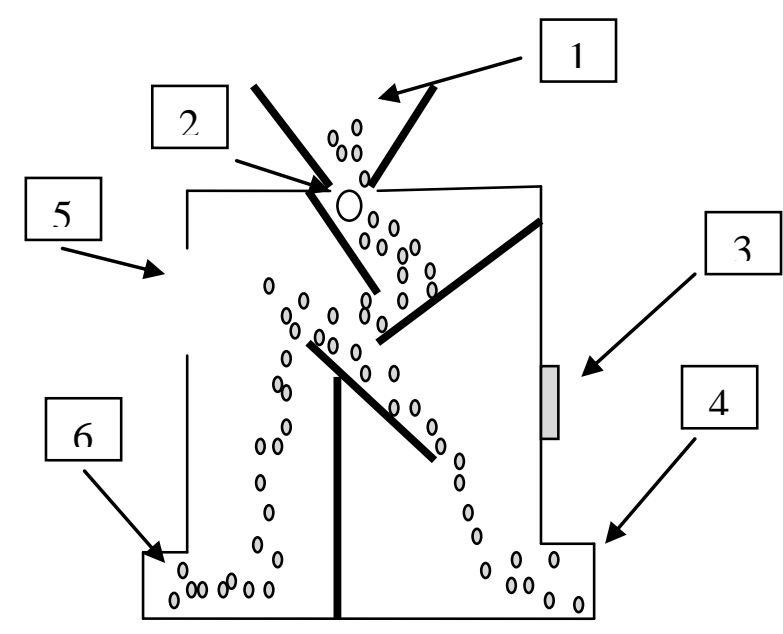

Gambar 4. Perancangan alat Pembersih Gabah otomatis

Pada perancangan Seed Cleaner otomatis ini menggunakan motor 2 buah DC 12 Volt dimana 1 motor digunakan untuk kipas dan 1 motor untuk belt conveyor pembawa padi. Seed cleaner terdiri atas 6 bagian

1. Bagian pemasukan gabah (hopper)

2. Belt memasukan Padi

3. Pully pengerak kipas (blower)

4. Lobang Udara Masuk

5. Padi yang teleh di bersihkan Kotoran

Untuk mengatur kecepatan putar kipas (blower) digunakan motor DC 12 Volt dengan konversi geer sehingga dapat memutar dan dikontrol menggunakan mikrokontroler untuk mengatur PWM motor agar dapat mengatur kecepatan motor. Disini kecepatan motor dicocokan dengan gabah yang akan dibersihkan, kecepatan motor diatur secara digital dengan menggunakan keypad agar didapatkan kecepatan yang dinginkan supaya dihasilkan gabah yang benar-benar baik.

Untuk menguji kecepatan yang dibutuhkan pengujian dilakukan pada dua sample jenis gabah yaitu gabah sokan dan gabah 42 dimana untuk kedua padi ini akan diuji dengan kecepatan berbeda agar didapatkan kecepatan putar yang baik dan juga pada gabah basah untuk menentukan kecepatan putar yang tepat. Untuk mengetahui kecepatan putar motor digunakan encoder sebagai sensor kecepatan dan Sensor Kelembaban agar nilai setting point yang diinginkan tercapai.

Pada perancangan Seed Cleaner yang umum digunakan tidak menggunakan belt conveyor untuk menaikan padi pada bagian pemasukan gabah (hopper) disini belt conveyor digunakan untuk mempermudah petani memasukan padi pada hopper dan juga belt conveyor dapat dikembangkan pada mesin perontok padi agar dapat bekerja secara berkesinambungan. Pada perancangan Seed Cleaner ini juga harus dapat dibawa oleh petani ke petak sawah jadi pembuatan alat ini juga harus ringan dan mudah dibawa oleh petani. Pada alat ini untuk kerangka pembersih gabah digunakan almunium sehingga Seed Cleaner ini ringan.

\section{Metode Fuzzy}

Pada metode perancangan fuzzy yang digunakan sebagai input sensor dari putaran motor adalah encoder dimana akan dibaca besaran putar permenit (RPM) dari motor. Setting point diinputkan dari keypad yang merupakan satuan dari RPM motor yang diharapkan. Input dari fuzzy itu sendiri adalah error (e) dan delta error (de). Dimana error adalah selisih dari nilai setpoint dari RPM motor yang diinginkan dengan data RPM yang terbaca. Sedangkan delta error adalah silisih antara error sekarang dengan error sebelumnya. Untuk keputusan outoput dari dua input fuzzy tersebut adalah PWM motor. Dimana nilai PWM yang akan di outputkan pada motor merupakan hasil defuzzifikasi dari proses. Dimana error adalah :

$\mathrm{e}(\mathrm{t})=\mathrm{SP}-\mathrm{C}$

dimana

$\mathrm{e}(\mathrm{t})=$ Error

$\mathrm{SP}=$ Set Point (RPM yang diinginkan)

$\mathrm{C}=$ Nilai RPM yang terbaca

Sedangkan delta error adalah selisih nilai RPM sebelumnya dengan nilai RPM sekarang. 
$\operatorname{de}(\mathrm{t})=\mathrm{e}(\mathrm{t})-\mathrm{e}_{(\mathrm{t}-1)}$

Dimana

$\operatorname{de}(\mathrm{t})=$ delta error

$\mathrm{e}(\mathrm{t}) \quad=$ error sekarang

$\mathrm{e}_{(\mathrm{t}-1)} \quad=$ Error Satu sampling sebelumnya

Fungsi keanggotan untuk posisi error (e) adalah

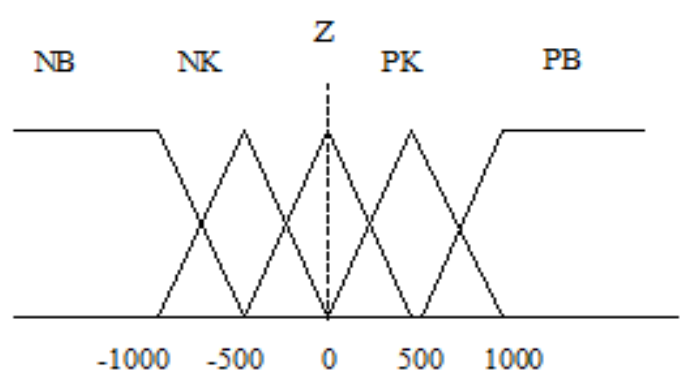

Gambar 5. Fungsi error sebagai input fuzzy

Keterangan Fungsi Keanggotaan error

NB : Negatif Besar (fungsi keanggotaan error kecil dari -500)

NK : Negatif Kecil (fungsi keanggotaan error kecil dari 0 dan besar dari -1000)

$\mathrm{Z}$ : Zero (Fungsi keanggotaan error kecil dari 50 dan besar dari -500)

PK : Positif Kecil (fungsi keanggotaan error kecil dari 1000 dan besar dari 0)

PB : Positif Besar (fungsi keanggotaan error besar dari 500)

Sedangkan untuk fungsi keanggotaan delta error (de)

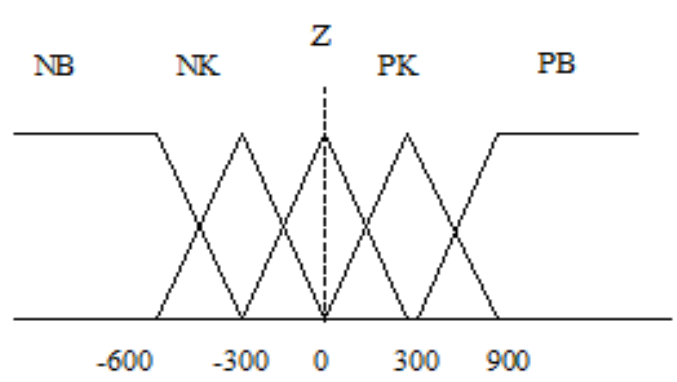

Gambar 6. Fungsi delta error sebagai input fuzzy

Keterangan Fungsi Keanggotaan delta error (de)
NB : Negatif Besar (fungsi keanggotaan error kecil dari -300)

NK : Negatif Kecil (fungsi keanggotaan error kecil dari 0 dan besar dari -600)

$\mathrm{Z} \quad$ : Zero (Fungsi keanggotaan error kecil dari 30 dan besar dari -300)

PK : Positif Kecil (fungsi keanggotaan Error kecil dari 600 dan besar dari 0)

PB : Positif Besar (fungsi keanggotaan error besar dari 300)

Sedangkan fungsi keputusan PWM yang diambil adalah

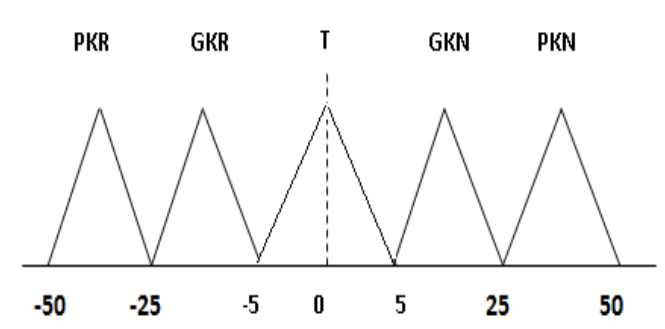

Gambar 7. Fungsi Keanggotan untuk PWM Motor

Keterangan Fungsi Keanggotaan Output PKR : Kurangkan PWM motor besar dari 25 dan Kurang dari 50

GKR : Kurangkan PWM motor besar dari 5 dan Kurang dari 25

T : Tambahkan PWM motor besar dari 0 dan kurang dari 5

Serta Kurangkan PWM motor besar dari 0 dan kurang dari 5

GKN : Tambahkan PWM motor besar dari 5 dan Kurang dari 25

PKN : Tambahkan PWM motor besar dari 25 dan Kurang dari 50 
Tabel 1. Rule Base

\begin{tabular}{|c|c|c|c|c|c|}
\hline $\mathbf{d e}(\mathbf{t})$ & NB & NK & $\mathbf{Z}$ & PK & PB \\
\hline NB & PKR & PKR & GKR & T & T \\
\hline NK & PKR & GKR & GKR & T & T \\
\hline $\mathbf{Z}$ & GKR & GKR & T & GKN & GKN \\
\hline PK & GKN & GKN & PKN & PKN & PKN \\
\hline PB & GKN & GKN & PKN & PKN & PKN \\
\hline
\end{tabular}

1. Jika Error NB (Negatif Besar) dan Delte Error NB (Negatif Besar) Maka Kurangkan Kecepatannya Besar (PKR)

2. Jika Error NB (Negatif Besar) dan Delte Error NK (Negatif Kecil) Maka Kurangkan Kecepatannya Besar (PKR)

3. Jika Error NB (Negatif Besar) dan Delte Error Z (Zero) Maka Kurangkan Kecepatannya Kecil (GKR)

4. Jika Error NB (Negatif Besar) dan Delte Error PK (Positif Kecil) Maka Tambahkan Kecepatannya Kecil $(\mathrm{GKN})$

5. Jika Error NB (Negatif Besar) dan Delte Error PB (Positip Besar) Maka Tambahkan Kecepatannya Kecil $(\mathrm{GKN})$

6. Jika Error NK (Negatif Kecil) dan Delte Error NB (Negatif Besar) Maka Kurangkan Kecepatannya Besar (PKR)

7. Jika Error NK (Negatif Kecil) dan Delte Error NK (Negatif Kecil) Maka Kurangkan Kecepatannya Kecil (GKR)

8. Jika Error NK (Negatif Kecil) dan Delte Error Z (Zero) Maka Kurangkan Kecepatannya Kecil (GKR)

9. Jika Error NK (Negatif Kecil) dan Delte Error PK (Positif Kecil) Maka Tambahkan Kecepatannya Kecil $(\mathrm{GKN})$

10. Jika Error NK (Negatif Kecil) dan Delte Error PB (Positip Besar) Maka Tambahkan Kecepatannya Kecil $(\mathrm{GKN})$

11. Jika Error Z (Zero) dan Delte Error NB (Negatif Besar) Maka Kurangkan Kecepatannya Kecil (GKR)
12. Jika Error Z (Zero) dan Delte Error NK (Negatif Kecil) Maka Kurangkan Kecepatannya Kecil (GKR)

13. Jika Error Z (Zero) dan Delte Error $Z$ (Zero) Maka Putaran motor Z (Zero)

14. Jika Error Z (Zero) dan Delte Error PK (Positif Kecil) Maka Tambahkan Kecepatannya Besar (PKN)

15. Jika Error Z (Zero) dan Delte Error PB (Positip Besar) Maka Tambahkan Kecepatannya Besar (PKN)

16. Jika Error PK (Positif Kecil) dan Delte Error NB (Negatif Besar) Maka Putaran motor Z (Zero)

17. Jika Error PK (Positif Kecil) dan Delte Error NK (Negatif Kecil) Maka Putaran motor Z (Zero)

18. Jika Error PK (Positif Kecil) dan Delte Error Z (Zero) Maka Kurangkan Kecepatannya Kecil (GKR)

19. Jika Error PK (Positif Kecil) dan Delte Error PK (Positif Kecil) Maka Tambahkan Kecepatannya Besar (PKN)

20. Jika Error PK (Positif Kecil) dan Delte Error PB (Positip Besar) Maka Tambahkan Kecepatannya Besar (PKN)

21. Jika Error PB (Positif Besar) dan Delte Error NB (Negatif Besar) Maka Putaran motor Z (Zero)

22. Jika Error PB (Positif Besar) dan Delte Error NK (Negatif Kecil) Maka Putaran motor Z (Zero)

23. Jika Error PB (Positif Besar) dan Delte Error Z (Zero) Maka Kurangkan Kecepatannya Kecil (GKR) 
24. Jika Error PB (Positif Besar) dan Delte Error PK (Positif Kecil) Maka Tambahkan Kecepatannya Besar (PKN)

25. Jika Error PB (Positif Besar) dan Delte Error PB (Positip Besar) Maka Tambahkan Kecepatannya Besar $(\mathrm{PKN})$

\section{HASIL DAN PEMBAHASAN}

\section{Pengujian Peralatan}

Tabel 2. Pengujian Kecepatan Motor dengan Beban tampa Kontoler

\begin{tabular}{|c|c|c|c|c|}
\hline No. & $\begin{array}{c}\text { Banyak } \\
\text { Batang } \\
\text { malai }\end{array}$ & $\begin{array}{c}\text { Kecepatan } \\
\text { awal } \\
\text { (RPM) }\end{array}$ & $\begin{array}{c}\text { Perlambatan } \\
\text { (RPM) }\end{array}$ & $\begin{array}{c}\text { Penurunan } \\
\text { Kecepatan }\end{array}$ \\
\hline 1 & 40 & 1000 & 870 & 130 \\
\hline 2 & 60 & 1000 & 750 & 350 \\
\hline 3 & 70 & 1000 & 650 & 550 \\
\hline 4 & 80 & 1000 & 610 & 900 \\
\hline 5 & 90 & 1000 & 510 & 990 \\
\hline 6 & 100 & 1000 & 390 & 1100 \\
\hline 7 & 110 & 1000 & 330 & 1170 \\
\hline 8 & 120 & 1000 & 200 & 1500 \\
\hline
\end{tabular}

\section{Kecepatan Motor}

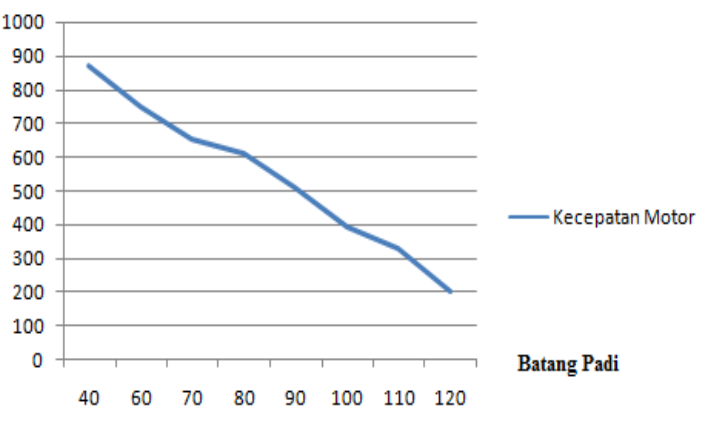

Gambar 8. Grafik Penurunan Kecepatan Motor dengan Penambahan Batang Padi

Hasil pengujian dapat diambil analisa bahwa tampa kontroler akan menyebabkan penurunan kecepatan putar dari motor ratarata 10 RPM setiap penambahan 1,3 batang malai.
Syarat Pengujian

1) Kecepatan putar mesin diatur pada kondisi 1000 RPM

2) Mesin yang digunakan harus kokoh, kuat dan aman.

3) Pengujian dilakukan setelah mesin berjalan stabil.

Pada pengujian pertama putaran mesin diuji dengan kecepatan 1000 RPM dimana motor DC tidak dikontroler

Pada pengujian kedua putaran mesin diuji dengan kecepatan 2000 RPM dimana motor DC dikontrol dengan menggunakan mikrontroler sensor yang digunakan adalah encoder. Pada pengujian kecepatan motor ini diharapkan kecepatan didapat constan walaupun diberi beban batang malai yang bervariasi. Untuk itu kontroler fuzzy digunakan untuk mengatur kecepatan motor dengan setting point dari kecepatan motor di set dengan menggunaan keypad. Mikrokontroler yang digunakan adalah arduino uno dengan input PWM yang dikontrol dengan menggunakan fuzzy logic kontroler. Hasil pada pengujian motor dengan menggunakan kontoler. 


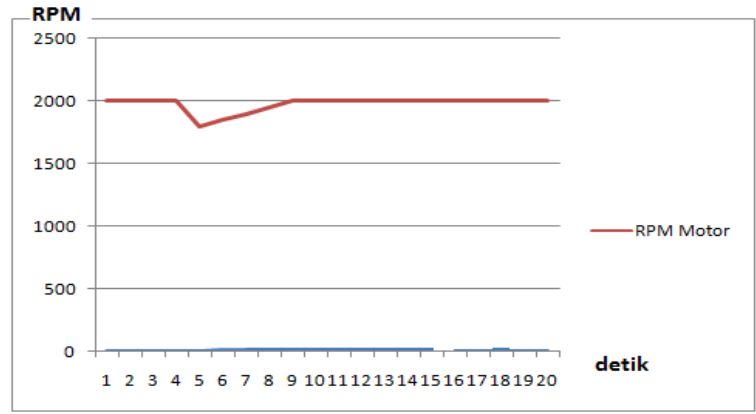

Gambar 9. Pengujian Kontoler motor dengan menggunaan fuzzy pada 50 batang Padi

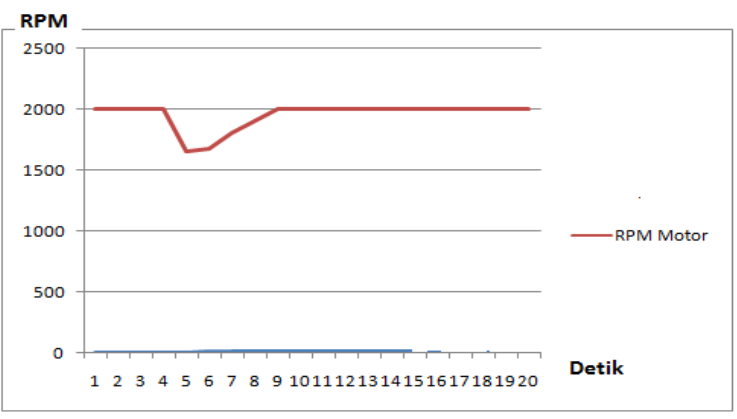

Gambar 10. Pengujian Kontoler motor dengan menggunaan fuzzy pada 80 batang Padi

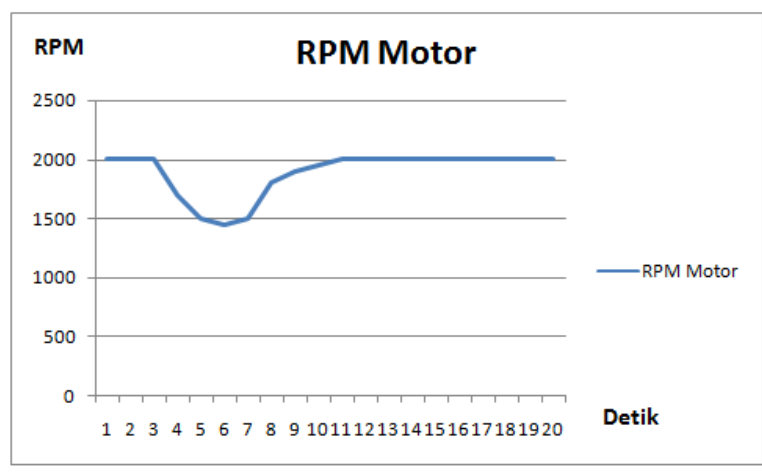

Gambar 11. Pengujian Kontoler motor dengan menggunaan fuzzy pada 100 batang Padi

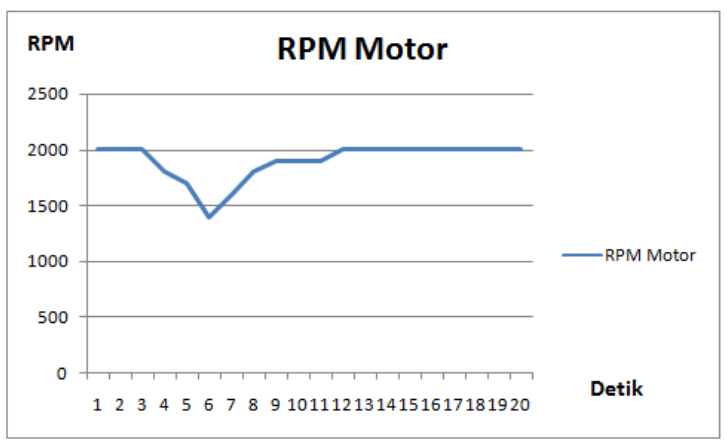

Gambar 12. Pengujian Kontoler motor dengan menggunaan fuzzy pada 130 batang Padi
Dari beberapa pengujian dapat dilihat Kontroler fuzzy bekerja untuk mengontrol kecepatan motor dengan memberikan beban bervariasi pada motor. Kontroler fuzzy bekerja ketika terjadi penurunan kecepatan yang disebabkan oleh masuknya batang padi pada mesin pemontok. Dari data didapatkan rata-rata waktu yang dibutuhkan oleh kontoler untuk menstabilkan kecepatan putar motor berkisar 6 detik tergantung dari cara meletakan batang padi pada mesin perontok.

Sedangkan pengujian daya yang digunakan oleh motor untuk merontok padi didapatkan arus motor ketika tampa beban sebesar 2,2 Amper dan ketika diberi beban rata-rata arus motor sebesar 6 Amper ini bervariasi terhadap beban yang diterima oleh motor.

Accu yang digunakan adalah 2 buah accu 45 Amper dengan teganngan $12 \mathrm{~V}$ sehingga Watt yang dihasil accu adalah 1080 Watt. Solar cell yang digunakan adalah kemampuan solar mencas 50 Watt maximum sehingga bila cuaca baik dan cahaya matahari maximum dari jam 10 pagi sampai 3 sore adalah 5 jam maka kemampuan cas accu sebesar 250 Watt sehingga untuk mencas accu sebesar 1080 dibutuhkan waktu 4 hari kerja.

Sedangkan penggunaan daya oleh motor adalah 40 Watt sampai 70 Watt maka bila accu digunakan 1080 Watt dan kemampuan accu bekerja sampai $40 \%$ maka alat perontok dapat bekerja maximum rata-rata selama 10 jam non stop.

\section{SIMPULAN}

Dari hasil pembahasan dan pengujian alat dapat disimpulkan

1. Penurunan kecepatan putar dari motor rata-rata 10 RPM setiap penambahan 1,3 batang malai.

2. Dibutuhkan waktu rata-rata 6 detik oleh kontoler untuk menstabilkan kecepatan putar motor pada kecepata 2000 RPM bila mesin Perontok diberi beban batang padi. 
3. Tingkat efesiensi perontok sebesar $96,5 \%$.

\section{DAFTAR PUSTAKA}

Monty Newborn. Kasparov versus Deep Blue: Computer chess comes of age. Springer, 1997.

Herbert A. Simon and Alan Newell. Heuristic problem solving: The next advance in operations research. Operations Research, 6(1):1-10, 1958.

Kusumadewi Sri, Purnomo Hari "Aplikasi Logika Fuzzy Untuk Pendukung Keputusan" Graha Ilmu, 2004

Bejo, Agus. (2007). C \& AVR' Rahasia Kemudahan Bahasa C Dalam Mikrokontroler Atmega 8535'. Yogyakarta: Graha Ilmu
Heryanto, M.Ary, dkk(2008). Pemograman Bahasa C untuk mikrokontroler AVR 8535. Yogyakarta: Andi

Inyong Ha, Yusuke Tamura, and Hajime Asama, (2011)'Development of Open Humanoid Platform DARwIn-OP' SICE Annual Conference, Waseda University, Tokyo, Japan.

ROBOTIS Co, Ltd. Web Site, "http://support.robotis.com/en/product/ dynamixel/dxl_communication.htm"

ROBOTIS Co, Ltd. Web Site, "http://support.robotis.com/en/product/ dynamixel/rx_series/rx-28.htm"

Winoto,A.(2008). Mikrokontroler AVR dan pemogramannya dengan bahasa $\mathrm{C}$. Jogjakarta: Gava media 